\title{
Respon Tanaman Brokoli (Brassica oleracea) terhadap Pupuk Organik Cair
}

The Response of Broccoli (Brassica oleracea) to Liquid Organic Fertilizer

\author{
Author(s): Fatiani Manik ${ }^{(1)}$; Bina Beru Karo ${ }^{(1)}$; Rina Christina Hutabarat ${ }^{(1)}$; \\ Darkam Musaddad ${ }^{(1)}$ \\ (1) Balai Penelitian Tanaman Sayuran, Kementerian Pertanian \\ * Corresponding author: fatianimanik@gmail.com
}

\begin{abstract}
ABSTRAK
Penggunaan pupuk organik sebagai alternatif pengganti pupuk anorganik dapat mengurangi pencemaran lingkungan. Tujuan dari penelitian ini adalah mengetahui pengaruh jenis dan konsentrasi pupuk organik cair (POC) terhadap pertumbuhan dan hasil brokoli (Brassica oleracea). Penelitian dilaksanakan di IP2TP Berastagi pada bulan Mei sampai dengan September 2020. Penelitian menggunakan Rancangan Acak Kelompok (RAK) dengan 3 kali ulangan dan 10 perlakuan. Perlakuan yang diuji adalah sebagai berikut: A: tanpa POC (Kontrol), B: POC kotciplus $10 \mathrm{ml} / \mathrm{L}, \mathrm{C}$ : POC kotciplus $20 \mathrm{ml} / \mathrm{L} \mathrm{D}$ : POC kotciplus $30 \mathrm{ml} / \mathrm{L}$, E: POC kipait $10 \mathrm{ml} / \mathrm{L}, \mathrm{F}$ : POC kipait $20 \mathrm{ml} / \mathrm{L}$, G: POC kipait 30 $\mathrm{ml} / \mathrm{L}, \mathrm{H}$ : POC limbah buah $10 \mathrm{ml} / \mathrm{L}$, I: POC limbah buah $20 \mathrm{ml} / \mathrm{L}, \mathrm{J}$ : POC limbah buah $30 \mathrm{ml} / \mathrm{L}$. Hasil penelitian menunjukkan bahwa POC yang terbaik adalah POC kotciplus. POC kotciplus $20 \mathrm{ml} / \mathrm{L}$, dan POC kotciplus $30 \mathrm{ml} / \mathrm{L}$ menunjukkan diameter kanopi terlebar yaitu masing-masing $(52,35 \mathrm{~cm}$ dan $51,71 \mathrm{~cm})$. Pemberian POC kotciplus $30 \mathrm{ml} / \mathrm{L}$ mampu meningkatkan hasil brokoli dilihat dari diameter bunga, bobot bunga per tanaman, bobot kuntum dan bobot bunga per plot.
\end{abstract}

\section{Kata Kunci:}

Brassica oleracea; hasil; pertumbuhan; POC

\section{ABSTRACT}

Keywords: $\quad$ The use of organic fertilizers is alternative to inorganic fertilizers for reducing the

Brassica oleraceae;

growth; organic;

POC environmental pollution. The aim of the research was to know the influence of the type and concentration of liquid organic fertilizer (POC) on the growth and yield of broccoli (Brassica oleracea). A field experiment was carried out at IP2TP Berastagi from May to September 2020. The experimental design used a randomized complete block design $(R C B D)$ with ten treatments and repeated three times. The treatments tested were as follows: A: without POC (Control), B: POC kotciplus $10 \mathrm{ml} / \mathrm{L}, \mathrm{C}:$ POC kotciplus $20 \mathrm{ml} / \mathrm{L}$, D: POC kotciplus $30 \mathrm{ml} / \mathrm{L}$, E: POC kipait $10 \mathrm{ml} / \mathrm{L}, \mathrm{F}:$ POC kipait $20 \mathrm{ml} / \mathrm{L}, \mathrm{G}:$ POC kipait $30 \mathrm{ml} / \mathrm{L}, \mathrm{H}$ : POC from fruit waste $10 \mathrm{ml} / \mathrm{L}, \mathrm{I}:$ POC from fruit waste $20 \mathrm{ml} / \mathrm{L}, \mathrm{J}:$ POC from fruit waste $30 \mathrm{ml} / \mathrm{L}$. The result showed that the best POC was POC kotciplus. POC Kotciplus $20 \mathrm{ml} / \mathrm{L}$ and POC kotciplus $30 \mathrm{ml} / \mathrm{L}$ show the widest canopy diameter respectively $(52,35 \mathrm{~cm}$ and $51,71 \mathrm{~cm})$. Application of POC kotciplus $30 \mathrm{ml} / \mathrm{L}$ was able to increase broccoli yield in terms of flower diameter, flower weight per plant, floret weight, and flower weight per plot. 


\section{PENDAHULUAN}

Brokoli ( Brassica oleracea L. var. italica) merupakan salah satu sayuran yang memiliki nilai gizi yang tinggi dan sangat bermanfaat bagi kesehatan manusia. Gad \& Abd El-Moez, (2011) menyatakan bahwa brokoli mengandung beberapa vitamin antara lain vitamin A, B1, B2, B5, B6 dan E. Selain itu mengandung unsur $\mathrm{Ca}, \mathrm{Mg}$, $\mathrm{Zn}$, dan Fe dan zat antioksidan.

Pupuk organik adalah pupuk yang berasal dari sisa tanaman, hewan atau manusia seperti pupuk kandang, pupuk hijau dan kompos yang mampu memperbaiki sifat fisik dan struktur tanah, kimia tanah, biologi tanah serta dapat meningkatkan daya menahan air dalam tanah (Firmansyah, Lukman, Khaririyatun, \& Yufdy, 2016). Penggunaan pupuk organic dengan kadar dan jenis yang disesuaikan fungsinya merupakan salah satu upaya dalam meningkatkan mutu tanah (agroekologi) dan tanaman (Wicaksana \& Sulistyono, 2017). Penerapan budidaya tanaman brokoli secara organik dapat mengurangi dampak pencemaran lingkungan karena aplikasinya tidak menggunakan bahan kimia, melainkan menggunakan bahan organik yang berasal dari limbah pertanian, peternakan, dan/atau perikanan.

Kotoran dan urin kelinci dapat digunakan sebagai alterntif media dan nutrisi dalam produksi sayuran karena memiliki kandungan unsur hara yang tinggi. Sumarni et al. (2015), menyatakan bahwa kotoran dan urine kelinci memiliki kandungan unsur $\mathrm{N} 2,72 \%, \mathrm{P} 1,1 \%, \mathrm{~K}$ $0,5 \%$ yang lebih tinggi dibandingkan dengan kotoran ternak lain seperti kuda, kerbau, sapi, domba, babi dan ayam. Nurrohman et al., (2014) menyatakan bahwa media fermentasi ekstrak paitan dan fermentasi kotoran kelinci cir dapat mensubstitusi nutrisi hidroponik.

Pupuk hijau yang bersumber dari tanaman Paitan (Tithonia diversifolia L) adalah tumbuhan perdu dari golongan
Asteraceae. Tithonia diversifolia mempunyai kelebihan yaitu waktu dekomposisi yang lebih cepat daripada tanaman lain serta unsur hara yang terkandung dalam tajuk $3,50-4,00 \% \mathrm{~N}$, 0,35-0,38\% P, 3,50-4,10\% K, 0,59\% Ca, dan 0,27\% Mg (Nurrohman et al., 2014; Lestari, 2016)). Pertumbuhan dan perkembangan tanaman jagung yang diberi perlakuan Tithonia diversifolia secara signifikan lebih baik dibandingkan dengan tanpa pemberian Tithonnia diversifolia (Oyerinde, Otusanya, \& Akpor, 2009).

Pupuk organik cair (POC) merupakan larutan dari hasil fermentasi bahan - bahan organik yang berasal dari sisa tanaman (limbah pasar) dan kotoran hewan. Pupuk organik cair dapat dipergunakan untuk semua jenis tanaman hortikultura, yang dilarutkan dalam air dan diaplikasikan lewat tanah maupun daun. Setiyowati et al., (2010) menyatakan bahwa pupuk organik cair berpengaruh terhadap peningkatan jumlah umbi dan berat basah umbi bawang merah pada konsentrasi 4-5 ml/L. Gomies et al., (2012) melaporkan bahwa pupuk organik cair RI1 hanya berpengaruh terhadap jumlah daun dan luas daun tanaman brokoli pada konsentrasi $4 \mathrm{ml} / \mathrm{L}$. Penelitian ini bertujuan untuk mengetahui pengaruh jenis dan konsentrasi pupuk organik cair (POC) terhadap pertumbuhan dan hasil brokoli (Brassica oleracea).

\section{METODOLOGI}

Penelitian ini dilaksanakan di kebun IP2TP Berastagi, Kabupaten Karo pada ketinggian \pm 1430 meter diatas permukaan laut dengan jenis tanah Andisol. Penelitian di laksanakan pada bulan Mei sampai September 2020. Bahan yang digunakan adalah benih brokoli varietas Royal Green, pupuk kandang ayam, kotoran kelinci, urin kelinci, tepung limbah ikan, EM-0, EM-4, air kelapa, kipait, limbah buah, dan gula.

Penelitian menggunakan Rancangan Acak Kelompok (RAK) dengan 3 kali 
ulangan dan 10 perlakuan. Perlakuan yang diuji adalah sebagai berikut : A: tanpa POC (kontrol), B: POC kotciplus $10 \mathrm{ml} / \mathrm{L}, \mathrm{C}$ : POC kotciplus $20 \mathrm{ml} / \mathrm{L}$, D: POC kotciplus $30 \mathrm{ml} / \mathrm{L}, \mathrm{E}:$ POC kipait $10 \mathrm{ml} / \mathrm{L}, \mathrm{F}:$ POC kipait $20 \mathrm{ml} / \mathrm{L}$, G: POC kipait $30 \mathrm{ml} / \mathrm{L}, \mathrm{H}$ : POC limbah buah $10 \mathrm{ml} / \mathrm{L}$, I: POC limbah buah $20 \mathrm{ml} / \mathrm{L}, \mathrm{J}$ : POC limbah buah 30 $\mathrm{ml} / \mathrm{L}$.

POC kotciplus terbuat dari kotoran kelinci $(4 \mathrm{~kg})+$ urin kelinci $(8 \mathrm{l})+$ tepung limbah ikan $(1 \mathrm{~kg})+$ efektifitas mikroorganisme generasi nol (1 l 1$)+$ air kelapa (1 1) yang difermentasikan selama 1 bulan (Marpaung, Udiarto, Lukman, \& Hardiyanto, 2019). POC kipait terbuat dari kipait $(25 \mathrm{~kg})+$ gula aren $(1 \mathrm{~kg})+$ air kelapa (25 1) + EM 4 (1 1) + air bersih. Air kelapa dan gula aren dimasukkan ke dalam tong plastik sambil diaduk kemudian tambahkan kipait dan EM 4 dan tambahkan air hingga $3 / 4$ tong plastik kapasitas 2001 , kemudian ditutup rapat, didiamkan selama 2 minggu. Bahan POC limbah buah adalah buah nenas $(30 \mathrm{~kg})+$ gula merah $(1 \mathrm{~kg})+$ EM4 (1 l) + air bersih. Cara pembuatannya adalah buah nenas beserta kulit dipotongpotong ukuran kecil dimasukkan ke dalam karung, diikat dimasukkan dalam tong plastik, tambahkan gula dan EM 4, kemudian ditambahkan air bersih sebanyak $3 / 4$ tong plastik kapasitas 2001 , ditutup rapat dan didiamkan selama 2 minggu. Pada saat penggunaan disaring terlebih dahulu.

Pengolahan tanah dilakukan 2 kali dengan tujuan untuk menggemburkan tanah, kemudian dilakukan pembersihan lahan, pembuatan bedengan dan ploting lahan percobaan. Bedengan dibuat dengan lebar $1 \mathrm{~m}$, panjang $10 \mathrm{~m}$ dan tinggi $30 \mathrm{~cm}$ sebanyak 30 plot. Jarak antara bedengan $0,5 \mathrm{~m}$ dan jarak antara ulangan $1 \mathrm{~m}$. Pupuk kandang ayam sebanyak $3 \mathrm{kgm}^{-1}$ ditabur secara merata di atas bedengan. Pupuk kandang ayam diberikan sebagai pupuk dasar untuk memperbaiki tekstur tanah. Setelah mulsa terpasang dibiarkan sekitar 2 minggu kemudian dilakukan pembuatan lubang tanam dengan jarak $30 \mathrm{~cm}$ x $30 \mathrm{~cm}$.

Aplikasi perlakuan POC dilakukan pada umur 2 minggu setelah tanam (MST) dan selanjutnya dilakukan setiap 2 minggu sekali sampai umur tanaman 12 MST dengan jenis dan konsentrasi sesuai perlakuan yang diuji dengan cara disemprotkan pada tajuk tanaman.

Peubah yang diamati antara lain adalah tinggi tanaman, jumlah daun, diameter kanopi, diameter bunga, bobot bunga per tanaman, jumlah kuntum per bunga, bobot kuntum dan bobot bunga per plot. Data yang diamati diuji dengan uji ANOVA (uji F) dan dilanjutkan dengan uji DMRT pada taraf 5\%.

\section{HASIL DAN PEMBAHASAN}

Hasil analisis tanah sebelum percobaan menunjukkan bahwa kandungan $\mathrm{C}$ - organik sangat tinggi yaitu $5,31 \%, \mathrm{~N}-$ total sedang 0,40 dan $\mathrm{C} / \mathrm{N}$ relatif rendah 13\%. Kandungan $\mathrm{P}_{2} \mathrm{O}_{5}$ dan $\mathrm{K}_{2} \mathrm{O}$ sangat tinggi yaitu $126 \mathrm{ppm}$ dan $113 \mathrm{ppm}$ (Tabel $1)$.

Hasil analisis POC kotciplus, POC kipait dan POC limbah buah dan sayur (Tabel 1), menunjukkan bahwa kandungan C-organik, $\mathrm{N}, \mathrm{P}_{2} \mathrm{O}_{5}$ dan $\mathrm{K}_{2} \mathrm{O}$ sangat rendah dibawah standar mutu persyaratan teknis minimal pupuk organik cair (Keputusan Mentri Pertanian RI 261/KPTS/SR.310/M/42/2019, 2019). Kandungan C/N POC Kotciplus adalah yang terbaik karena kandungan $\mathrm{C} / \mathrm{N}$ nya mendekati $\mathrm{C} / \mathrm{N}$ tanah. Wardhana et al., (2021) menyatakan bahwa semakin dekat rasio $\mathrm{C} / \mathrm{N}$ pupuk organik terhadap tanah, maka memudahkan tanaman dalam menyerap makro dan mikro hara. Sitompul et al., (2017) menyatakan bahwa prinsip pengomposan adalah menurunkan $\mathrm{C} / \mathrm{N}$ rasio bahan organik sehingga sama dengan tanah $(<20)$.

Hasil analisis statistik pengaruh POC terhadap tinggi tanaman secara umum menunjukkan adanya pengaruh yang nyata 
pada umur 2 MST dibandingkan dengan kontrol. Sedangkan pada umur 3-6 MST, aplikasi POC tidak berpengaruh nyata terhadap tinggi tanaman (Gambar 1).

Tabel 1. Data Analisis Tanah Sebelum Perlakuan dan Analisis POC Kotciplus, POC Kipait dan POC Limbah Buah

Table 1. Soil analysis data before treatment and analysis of kotciplus POC, kipait POC and fruit waste POC

\begin{tabular}{lllll}
\hline $\begin{array}{l}\text { Parameter } \\
\text { Parameter }\end{array}$ & $\begin{array}{l}\text { Tanah } \\
\text { Soil }\end{array}$ & $\begin{array}{l}\text { POC Kotciplus } \\
\text { Liquid organic } \\
\text { fertilizer kotciplus }\end{array}$ & $\begin{array}{l}\text { POC Kipait } \\
\text { Liquid organic } \\
\text { fertilizer kipait }\end{array}$ & $\begin{array}{l}\text { POC Limbah } \\
\text { buah } \\
\text { Liquid organic } \\
\text { fruit waste }\end{array}$ \\
\hline C-organik (\%) & 5,31 & 1,80 & 1,11 & 0,86 \\
N Total (\%) & 0,40 & 0,11 & 0,05 & 0,03 \\
$\mathrm{C} / \mathrm{N}(\%)$ & 13 & 16 & 22 & 29 \\
$\mathrm{P}_{2} \mathrm{O}_{5}(\%)$ & - & 0,01 & 0,02 & 0,01 \\
$\mathrm{~K}_{2} \mathrm{O}(\%)$ & - & 0,46 & 0,10 & 0,05 \\
$\mathrm{P}_{2} \mathrm{O}_{5}(\mathrm{ppm})$ & 126 & - & - & - \\
$\mathrm{K}_{2} \mathrm{O}(\mathrm{ppm})$ & 113 & - & - & - \\
\hline
\end{tabular}

Sumber: Laboratorium Terpadu Balai Penelitian Tanaman Sayuran,2020.

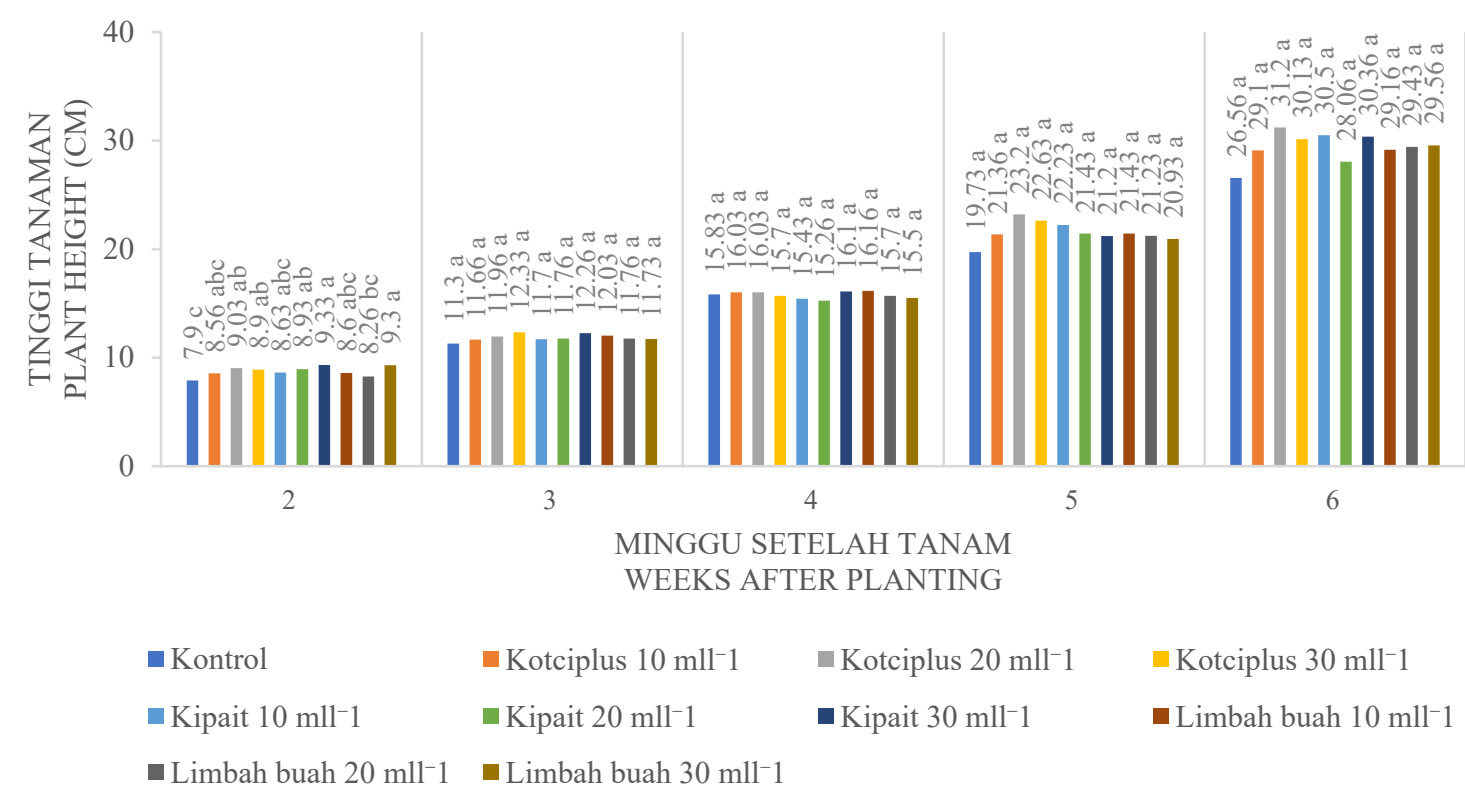

Gambar 1. Respon Tinggi Tanaman Brokoli terhadap Jenis Pupuk Organik Cair

Figure 1. Response plant height of broccoli to type liquid organic fertilizer

Pada awal pengamatan (umur 2 ini menunjukkan bahwa pemberian MST), seluruh perlakuan POC fermentasi ekstrak kipait dan limbah buah berpengaruh nyata terhadap tinggi tanaman dibandingkan dengan kontrol. Tanaman tertinggi ditunjukkan pada perlakuan POC kipait $30 \mathrm{ml} / \mathrm{L}$ kemudian diikuti oleh perlakuan POC limbah buah $30 \mathrm{ml} / \mathrm{L}$. Hal pada dosis $30 \mathrm{ml} / \mathrm{L}$ mampu meningkatkan tinggi tanaman. Akan tetapi pada pengamatan 3-6 MST pemberian POC tidak berpengaruh terhadap tinggi tanaman brokoli. 
Aplikasi ragam POC tidak menunjukkan perbedaan yang nyata terhadap pertambahan jumlah daun tanaman brokoli pada umur 2-6 MST (Gambar 2). Perlakuan POC tidak berbeda nyata dengan kontrol, hal ini diduga karena kadar $\mathrm{N}$ dalam tanah lebih tinggi daripada

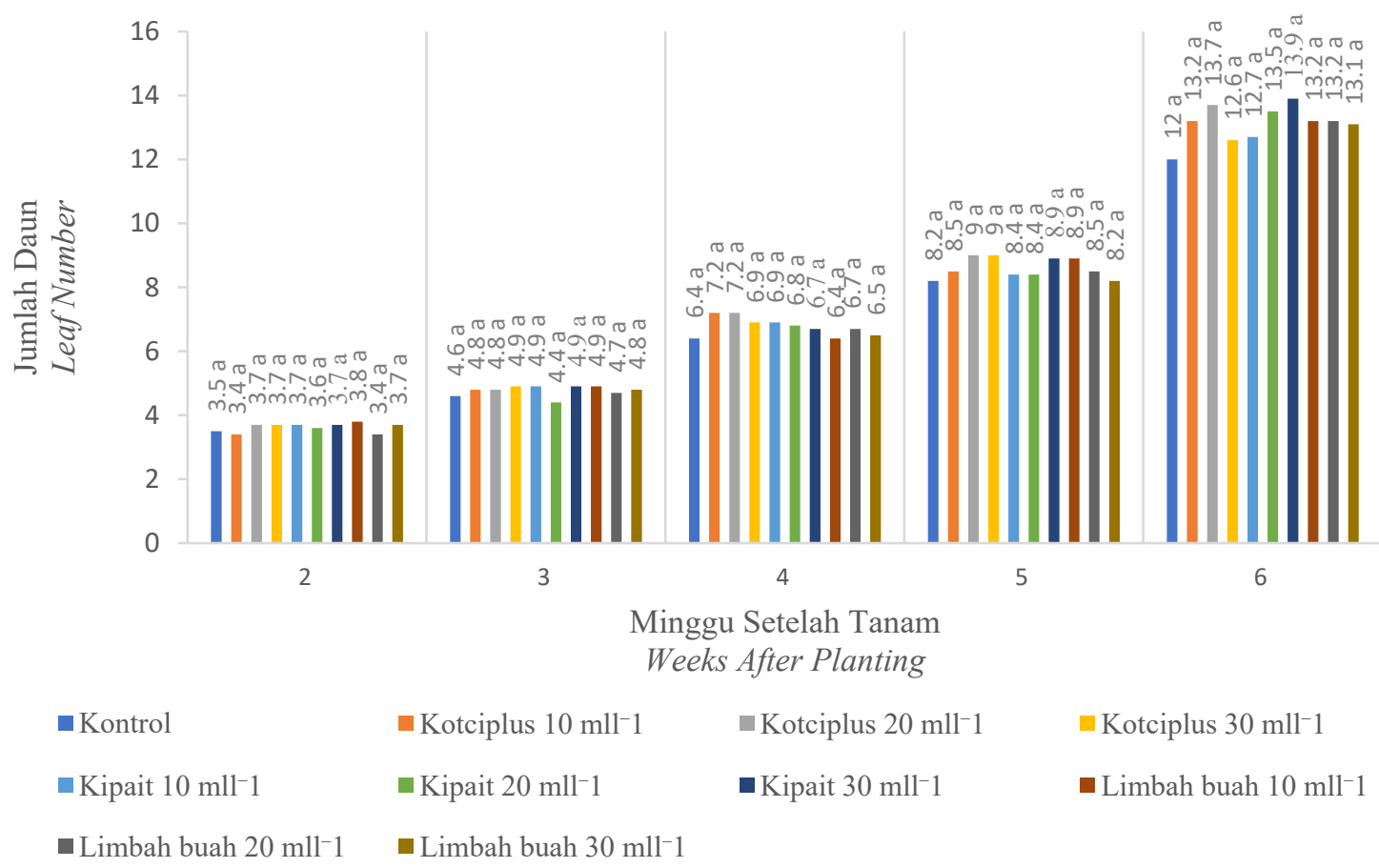

Gambar 2. Respon Jumlah Daun Brokoli terhadap Jenis Pupuk Organik Cair

Figure 2. Response leaf number of broccoli to type liquid organic fertilizer

Pemberian ragam POC tidak berpengaruh nyata terhadap diameter kanopi tanaman brokoli sampai umur 5 MST, namun pada umur 6 MST menunjukkan respon yang nyata dengan data diameter kanopi tertinggi ditunjukkan oleh perlakuan POC kotciplus $20 \mathrm{ml} / \mathrm{L}$ dan POC kotciplus $30 \mathrm{ml} / \mathrm{L}$, sedangkan kanopi yang terkecil adalah perlakuan POC limbah buah $30 \mathrm{ml} / \mathrm{L}$ dan kontrol (Gambar $3)$.

Aplikasi perlakuan POC kotciplus 20 $\mathrm{ml} / \mathrm{L}$ efisien meningkatkan luas kanopi tanaman brokoli, hal ini menunjukkan bahwa POC kotciplus pada konsentrasi 20 $\mathrm{ml} / \mathrm{L}$ lebih unggul dibandingkan dengan POC kipait dan POC limbah buah. Hal ini diduga karena dari semua perlakuan, POC yang terkandung pada POC. Hal ini sesuai dengan pernyataan Agyeman et al., (2013) bahwa jika suatu jenis pupuk organik atau bahan organik mempunyai kadar $\mathrm{N}$ rendah, lignin akan terhambat, hanya sedikit $\mathrm{N}$ sisa yang dapat dimanfaatkan oleh tanaman. 
dengan pembentukan biomassa tanaman. Ratna (2002) menyatakan bahwa peningkatan luas daun merupakan upaya tanaman dalam mengefisiensikan penangkapan energi cahaya untuk fotosintesis secara normal pada kondisi intensitas cahaya rendah.

Aplikasi ragam POC berpengaruh nyata terhadap diameter bunga, bobot bunga per tanaman, bobot kuntum dan bobot bunga per plot, namun tidak berpengaruh nyata terhadap jumlah kuntum per bunga (Tabel 2). Produksi bunga brokoli pada perlakuan POC kotciplus $30 \mathrm{ml} / \mathrm{L}$ berbeda sangat nyata dengan kontrol (Gambar 4). Hal ini menunjukkan bahwa dengan pemberian POC kotciplus $30 \mathrm{ml} / \mathrm{L}$ mampu meningkatkan produksi bunga brokoli dengan nilai tertinggi yang ditunjukkan pada variabel diameter bunga, bobot bunga per tanaman, bobot kuntum dan bobot bunga per plot. Hasil penelitian Pitoyo et al., (2012) menyebutkan bahwa pemberian urin kelinci pada dosis $30 \mathrm{ml} \mathrm{l}^{-1}$ setiap 8 hari sekali mulai umur 8 HST sampai 45 HST mampu meningkatkan produksi bunga brokoli dibandingkan dengan kontrol.

Perlakuan ragam POC tidak berpengaruh nyata terhadap jumlah kuntum per bunga. Jumlah kuntum per bunga tidak berbeda nyata dengan kontrol dengan rata-rata jumlah kuntum per bunga adalah sebanyak 7,29 kuntum.

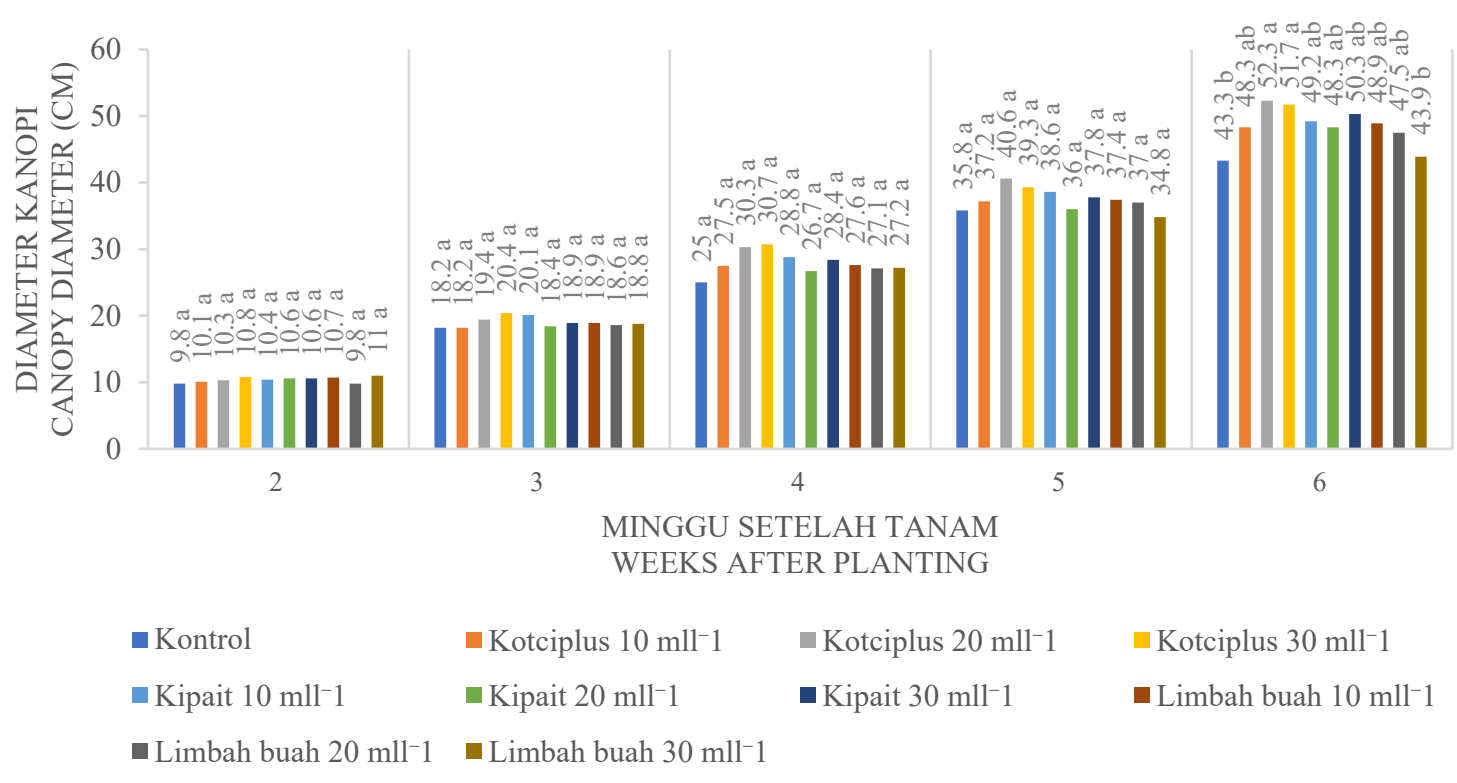

Gambar 3. Respon Diameter Kanopi Brokoli terhadap Jenis Pupuk Orgaik Cair Figure 3. Response canopy diameter of broccoli to type liquid organic fertilizer 
Tabel 2. Respon Produksi Bunga Brokoli terhadap Jenis Pupuk Organik Cair Table 2. Response flower production of broccoli to type liquid organic fertilizer

\begin{tabular}{|c|c|c|c|c|c|}
\hline $\begin{array}{l}\text { POC } \\
\text { Liquid organic fertilizer }\end{array}$ & $\begin{array}{l}\text { Diameter } \\
\text { bunga } \\
\text { Flower } \\
\text { diameter }(\mathrm{cm})\end{array}$ & $\begin{array}{l}\text { Bobot } \\
\text { bunga/ } \\
\text { tanaman } \\
\text { Weight of } \\
\text { flower/plant } \\
(g)\end{array}$ & $\begin{array}{l}\text { Jumlah } \\
\text { kuntum/ } \\
\text { bunga } \\
\text { Number of } \\
\text { buds/flower }\end{array}$ & $\begin{array}{l}\text { Bobot } \\
\text { kuntum } \\
\text { Weight of } \\
\text { buds (g) }\end{array}$ & $\begin{array}{l}\text { Bobot } \\
\text { bunga/ } \\
\text { plot } \\
\text { Weight } \\
\text { flower/plot } \\
\text { (g) }\end{array}$ \\
\hline Kontrol & $11,40 \mathrm{~b}$ & $628,8 \mathrm{~b}$ & $19,66 \mathrm{a}$ & $9,56 \mathrm{~b}$ & $27233 d$ \\
\hline Kotciplus $10 \mathrm{ml} / \mathrm{L}$ & $14,45 \mathrm{ab}$ & $802,7 \mathrm{ab}$ & $20,40 \mathrm{a}$ & $12,80 \mathrm{ab}$ & $35667 \mathrm{c}$ \\
\hline Kotciplus $20 \mathrm{ml} / \mathrm{L}$ & $14,26 \mathrm{ab}$ & $875,7 \mathrm{ab}$ & $20,86 \mathrm{a}$ & $11,20 \mathrm{~b}$ & $43400 \mathrm{ab}$ \\
\hline Kotciplus $30 \mathrm{ml} / \mathrm{L}$ & $16,05 \mathrm{a}$ & $1032,3 \mathrm{a}$ & $21,93 \mathrm{a}$ & $17,80 \mathrm{a}$ & $47967 \mathrm{a}$ \\
\hline Kipait $10 \mathrm{ml} / \mathrm{L}$ & $13,83 \mathrm{ab}$ & $809,7 \mathrm{ab}$ & $20,46 \mathrm{a}$ & $12,80 \mathrm{ab}$ & $37333 \mathrm{bc}$ \\
\hline Kipait $20 \mathrm{ml} / \mathrm{L}$ & $12,41 \mathrm{ab}$ & $741,7 \mathrm{~b}$ & $19,80 \mathrm{a}$ & $12,50 \mathrm{ab}$ & $38300 \mathrm{bc}$ \\
\hline Kipait $30 \mathrm{ml} / \mathrm{L}$ & $12,61 \mathrm{ab}$ & $731,0 \mathrm{~b}$ & $22,08 \mathrm{a}$ & $12,13 a b$ & $40733 \mathrm{bc}$ \\
\hline Limbah buah $10 \mathrm{ml} / \mathrm{L}$ & $14,88 \mathrm{ab}$ & $852,0 \mathrm{ab}$ & $21,26 \mathrm{a}$ & $10,90 \mathrm{~b}$ & $34700 \mathrm{c}$ \\
\hline Limbah buah $20 \mathrm{ml} / \mathrm{L}$ & $11,88 \mathrm{ab}$ & $629,3 \mathrm{~b}$ & $20,13 \mathrm{a}$ & $11,80 a b$ & $41267 \mathrm{abc}$ \\
\hline Limbah buah $30 \mathrm{ml} / \mathrm{L}$ & $14,11 \mathrm{ab}$ & $875,7 \mathrm{ab}$ & $20,13 \mathrm{a}$ & $13,03 \mathrm{ab}$ & $42867 \mathrm{ab}$ \\
\hline Rata-rata & - & - & 20,67 & - & - \\
\hline KK & 7,31 & 8,78 & 7,29 & 11,42 & 9.54 \\
\hline
\end{tabular}

Keterangan :

Angka-angka pada kolom yang sama yang diikuti oleh huruf yang berbeda menunjukkan berbeda nyata menurut uji DMRT pada taraf 5\%.

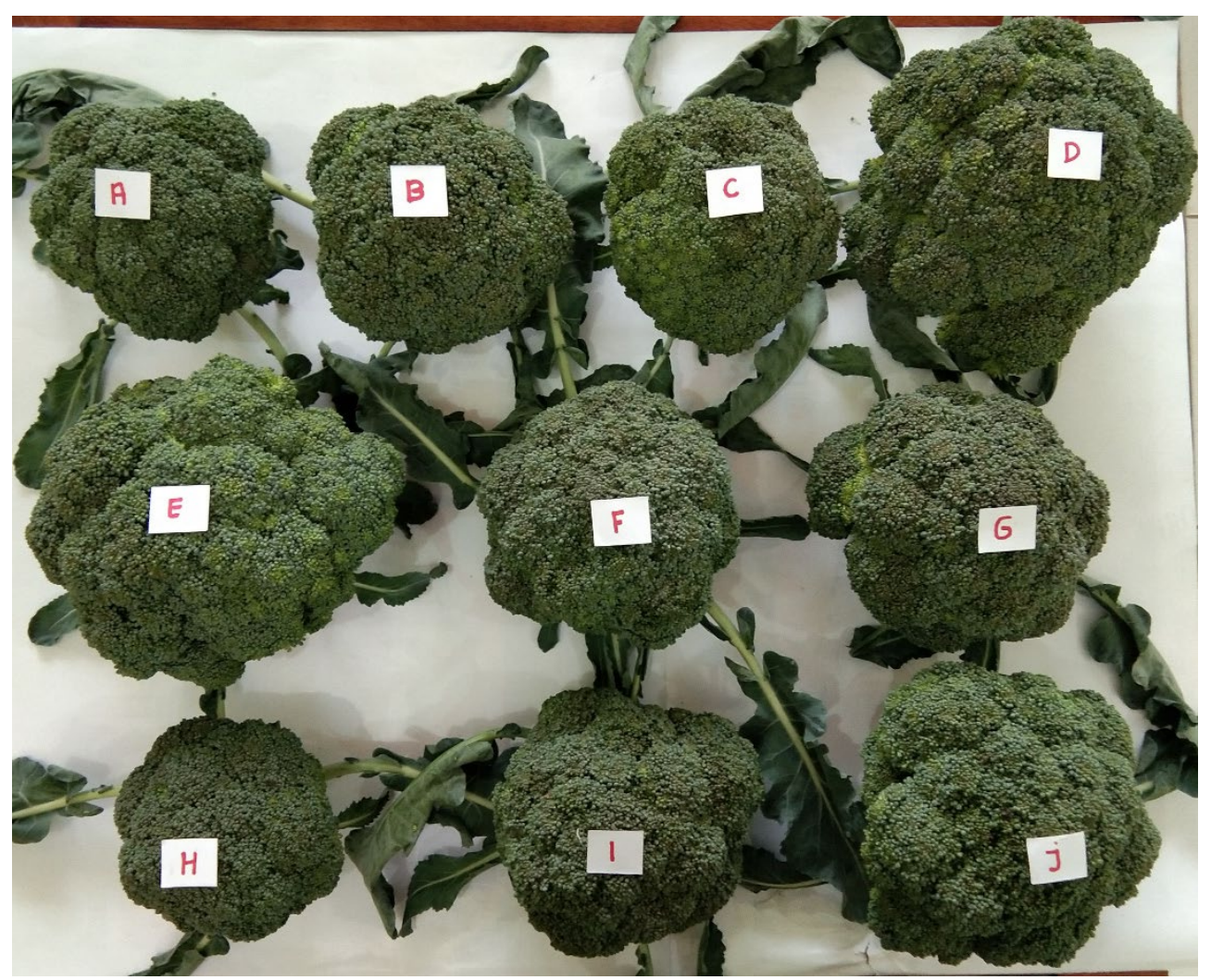

Gambar 4. Bunga brokoli dengan perlakuan ragam POC Figure 4. Broccoli flowers with various POC treatments 


\section{KESIMPULAN}

Hasil penelitian dapat disimpulkan bahwa POC yang terbaik adalah POC kotciplus. POC kotciplus $20 \mathrm{ml} / \mathrm{L}$, dan POC kotciplus $30 \mathrm{ml} / \mathrm{L}$ menunjukkan diameter kanopi terlebar yaitu masingmasing $(52,35 \mathrm{~cm}$ dan $51,71 \mathrm{~cm})$. Pemberian POC kotciplus $30 \mathrm{ml} / \mathrm{L}$ mampu meningkatkan hasil brokoli dilihat dari diameter bunga, bobot bunga per tanaman, bobot kuntum dan bobot bunga per plot.

\section{DAFTAR PUSTAKA}

Agyeman, K., Berchie, J. N., Gaisie, E., \& Adomako, J. (2013). Synchronization of Nutrient Release from Gliricidia sepium with Nutrient Uptake by Maize Through Biomass Decomposition. International Journal of Science and Advanced Technology, 3(3), 49-56.

Astari, K., Yuniarti, A., Sofyan, E. T., \& EQ Setiawati, M. R. (2016). Pengaruh Kombinasi Pupuk N, P, K dan Vermikompos terhadap Kandungan C-organik, $\mathrm{N}$ Total, $\mathrm{C} / \mathrm{N}$ dan Hasil Kedelai. Agroekotek, 8(2), 95-103.

Firmansyah, I., Lukman, L., Khaririyatun, E. \& \& Yufdy, M. P. (2016). Pertumbuhan dan Hasil Bawang Merah dengan Aplikasi Pupuk Organik dan Pupuk Hayati pada Tanah Alluvial. Jurnal Hortikultura, 25(2), 133.

Gad, N., \& Abd El-Moez, M. (2011).

钢 Broccoli growth, yield quantity and quality as affected by cobalt nutrition. Agriculture and Biology Journal of North America, 2(2), 226231.

Gomies, L., Rehatta, H., \& Jean Nendissa, J. (2018). Pengaruh Pupuk Organik Cair Ri1 Terhadap Pertumbuhan Dan Produksi Tanaman Kubis Bunga
(Brassica oleracea var. botrytis L.). Agrologia, 1(1), 13-20.

Keputusan Mentri Pertanian RI

EQ 261/KPTS/SR.310/M/42/2019,

[KEPMENTAN].

(2019).

Persyaratan Teknis Minimal Pupuk Organik, Pupuk Hayati, dan Pembenah Tanah. Keputusan Menteri Pertanian Republik Indonesia No 261.

Lestari, S. A. D. (2016). Pemanfaatan EQ Paitan (Tithonia diversifolia) sebagai Pupuk Organik pada Tanaman Kedelai. Iptek Tanaman Pangan, 11(1), 49-56.

Marpaung, A. E., Udiarto, B. K., Lukman, E. \& \& Hardiyanto, N. (2019). Potensi Pemanfaatan Formulasi Pupuk Organik Sumber Daya Lokal untuk Budidaya Kubis (Potential Use Formulation of Fertilizer Local Natural Resources for Cabbage Plantation). Jurnal Hortikultura, 28(2), 191.

Nurrohman, M., Suryanto, A., \& Puji, K. (2014). Penggunaan Fermentasi Ekstra Paitan (Tithonia diversifolia L.) dan Kotoran Kelinci Cair Sebagai Sumber Hara pada Budidaya Sawi (Brassica juncea L.) Secara Rakit Apung. Jurnal Produksi Tanaman, 2(8), 649-657.

Oyerinde, R. O., Otusanya, O. O., \& Akpor, O. B. (2009). Allelopathic Effect of Tithonia diversifolia on the Germination, Growth and Chlorophyll Contents of Maize (Zea mays L.). Scientific Research and Essays, 4(12), 1553-1558.

Pitoyo, Supriyadi, T., \& Daryanti. (2012). 顽 Pengaruh Pupuk Organik Cair dan Dosis Urin Kelinci pada Pertumbuhan dan Hasil Brocoli. 
Agrineca, 12(1), 63-74.

Setiyowati, S., Haryanti, S., \& Hastuti, R.

E. (2012). Pengaruh Perbedaan Konsentrasi Pupuk Organik Cair tehadap Produksi Bawang Merah (Allium ascalonicum L). Bioma: Berkala Ilmiah Biologi, 12(2), 44.

Sitompul, E., Wardhana, I. wisnu, \& El Sutrisno, E. (2017). Studi Identifikasi Rasio C/N Pengolahan Sampah Organik Sayuran Sawi, Daun Singkong, Dan Kotoran Kambing Dengan Variasi Komposisi Menggunakan Metode Vermikomposting. Jurnal Teknik Lingkungan, 6(2), 1-12.

Wardhana, M. A., Setyaningrum, A., \& EQ Soediarto, P. (2021). Pengaruh Level Aktivator yang Dibuat dengan Media Buah Maja (Aegle marmelos) Terhadap Rasio C/N dan Kinetika PH Pupuk Organik Padat Sapi Potong. Prosiding Seminar Teknologi Agribisnis Peternakan (Stap) Fakultas Peternakan Universitas Jenderal Soedirman, 8, 98-104.

Wicaksana, P. C., \& Sulistyono, N. B. E. 鹤 (2017). Aplikasi Pupuk Kandang Ayam dan Mikroorganisme Lokal (MOL) Daun Gamal Terhadap Produksi dan Mutu Benih Mentimun (Cucumis sativus L.). Agriprima: Journal of Applied Agricultural Sciences, 1(1), 72-85.

Wijaya, K. (2010). Pengaruh Konsentrasi 尌 dan Frekuensi Pemberian Pupuk Organik Cair Hasil Perombakan Anaerob Limbah Makanan terhadap Pertumbuhan Tanaman Sawi (. Skripsi, 1-55. 